\title{
Organizing the space of possibilities of an architectural competition
}

\author{
Jan Silberberger, Fribourg
}

\section{Introduction}

According to SoRkIN (2005), the Post World Trade Center Design Competition was a mere «as-if». The decision to run a competition promised opportunity to develop, discuss and maybe even realise extraordinary propositions for «Ground Zero», propositions that would give priority to memorial instead of economical aspects. Yet, it turned out that the result of the competition had been set right from the start. SoRKIN points out that every relevant issue had been decided «behind the scenes, without formal accountability» (2005: 108) long before the competition was announced, which resulted in a competition brief so narrow that only a limited number of minor decisions remained to be taken by the competing architecture offices and - in consequence in competition entries varying only with regard to the shape of their exterior form.

Referring to PløGER (2008), who has shown the relevance of the foucauldian concept of «dispositif» for urban planning, VAN WEZEMAEL et al. (2011) conducted an empirical study examining a series of early Swiss architectural competitions concerning post office buildings and identified this series of competitions as a foucauldian dispositif. That is, they described it as a «situational ensemble of forces of becoming», which allowed the new founded Swiss republic to «sell» its ideals (by transcribing them into its built environment) to a population, which had been sceptical towards the idea of a central state. In the same way, according to SoRkin (2005), the Post World Trade Center Design Competition can be regarded as a staging or a device to «sell» the client's request to the public: running a competition allowed for realising a rather dull project (targeting mainly profitable office space) on a site that has been (and still is) so much the centre of attention and has been attracting such a diversity of architectural propositions.

Although Sorkin's description of the Post World Trade Center Design Competition might deal with an extreme case (with regard to the approach of the client conducting the competition as well as to the «scale» of the task), it suitably raises awareness for what happens before an architectural competition is officially announced and therefore for the preparation stage of such a competition. This article thus focuses on the manner in which competition briefs organize the competitions" «solution space» (Kreiner 2006, 2007a, 2007b, 2009).

\section{Research focus}

At the very beginning of an architectural competition there is - quite obviously - a client with a specific request. In order to develop this request, the client usually hires an architectural office to carry out a socalled «development study» (or «preparatory study»). This study analyses the client's request with reference to available budget, as well as planning and building laws and regulations. Within the scope of a development study a number of possible volumetric variants are produced to show how the client's request might look in consideration of the given restrictions. In the course of such a development study, and in particular due to the accompanying frequent exchanges between the architecture office's employees and the client's representatives, the client's request usually becomes increasingly clear, more and more definite and more and more detailed. This defined and detailed request finally provides the basis for writing the competition programme. The question - and this paper's topic - is how this detailed request or (relatively) definite idea is translated into a competition programme that encourages different, yet comparable and in particular realisable, architectural propositions; that generates scope for the competing architecture offices and therefore a certain variety of architectural propositions and yet, at the same time, forces the competing architectural firms to produce adequate architectural propositions.

\section{Methodology}

The research approach chosen to explore the above question is an ethnographic study of decision-making processes in the course of four different architectural competitions in Switzerland (Figure 1). The study methodologically draws on the work of LATOUR and Woolgar (1979) and Yaneva (2009). Latour and Woolgar published observations made of scientists working in a bio-chemical laboratory. Over a period of two years, LATOUR occupied an office within a scientific laboratory and observed how the scientists went about constructing scientific facts. Similarly, YanEva studied the work of architects at the office of REM KoolHaAs by observing the decision-making process of the architects when designing a building. For this article, attention was paid to the process involved in the writing-up of competition programmes. The researcher attended sessions where teams were preparing competition briefs. While observing, the researcher «guess[ed] at meanings» and «assess[ed] the guesses» (GEERTz 1975: 20). That is, he interpreted his observations and 


\begin{tabular}{|l|c|c|c|c|}
\hline & Basel & Zurich & Winterthur & Berne \\
\hline Building Type & $\begin{array}{c}\text { Extension to the Basel } \\
\text { Kunstmuseum }\end{array}$ & \multicolumn{3}{|c|}{ Apartment complex } \\
\hline Project Budget & $\begin{array}{c}100 \text { Mio. CHF } \\
\text { (68 Mio. EUR) }\end{array}$ & $\begin{array}{c}\text { 50 Mio. CHF } \\
\text { (34 Mio. EUR) }\end{array}$ & $\begin{array}{c}\text { 54 Mio. CHF } \\
\text { (37 Mio. EUR) }\end{array}$ & $\begin{array}{c}\text { 35 Mio. CHF } \\
\text { (24 Mio. EUR) }\end{array}$ \\
\hline Competition Type & \multicolumn{3}{|c|}{ anonymous, selective procedure } & anonymous, open \\
\hline Client & Public & $\begin{array}{c}\text { 2/3 Public } \\
1 / 3 \text { Private }\end{array}$ & Public & Private \\
\hline
\end{tabular}

Fig.1: Key facts of the four architectural competitions observed

Basisdaten zu den vier untersuchten Architekturwettbewerben

Eléments clés des quatre concours d'architecture considérés

discussed these interpretations with the people being observed. In this manner, he verified/falsified his interpretations during the course of the observation series. Three extracts from these observations (which were originally noted in German and then translated by the author) are presented and discussed below.

\section{Architectural competitions: a basic definition}

According to KohouteK (2005) and Van Wezemael (2010), architectural competitions may be seen as «sorting machines». VAN WEZEMAEL (2010:274) argues that the

«competition process moves step by step towards a new possible actualisation of a place, separating out most potential solutions and manifesting only one urban future».

Following VAN WEZEMAEL architectural competitions can be regarded as devices that organize a given site's «space of possibilities» (DELANDA 2002). Architectural competitions sort the imaginable future scenarios for a given site. By means of a series of sorting processes they determine which future scenarios can be considered suitable and which have to be considered impossible. As mentioned above, the paper at hand focuses on the sorting process accompanying the translation of a detailed request (generated through a development study) into a competition programme.

\section{Findings of case studies: translating a detailed request into a competition programme}

The dialogue below stems from the beginning of a jury assessment session. Juror A and B (both professional architects) have already been familiarised with the respective project and proceed to introduce it to their fellow jurors.

Extract 1 (p. 7) illustrates how the client and/or the jury of an architectural competition are not simply looking for a project that fulfils all programme givens and specifications. In line 6, juror A refers to the project, which adheres closely to the competition programme as «the best pupil». Noticing that some of his fellow jurors understood his remark as clear disapproval, he adds that this is «no judgement» - however, without completely clearing the notion of disapproval. If one takes into account that the respective competition had a brief comprising a lot of givens and specifications with some of them «tricky to fulfil» (as jurors expressed on various occasions referring to the issue of conflicting specifications), juror A's remark (line 6) might seem rigorous. However, from a different perspective, that remark simply demonstrates that fulfilling the givens and specifications is to be regarded as a sort of precondition and that an important part of the architect's work lies beyond it.

At this point, WEICK's (2006) terms «fancy» and «imagination» as explained in KREINER (2007b) can be introduced. WeIcK defines fancy as the

«power of inventing the novel and unreal by recombining the elements found in reality»

and imagination as the

«ability to conceive of something, seen only fragmentarily or superficially, as a complete, perfected, and integral whole» (2006: 447).

One can argue that both skills are demanded from competing architecture offices, in the sense that it is 


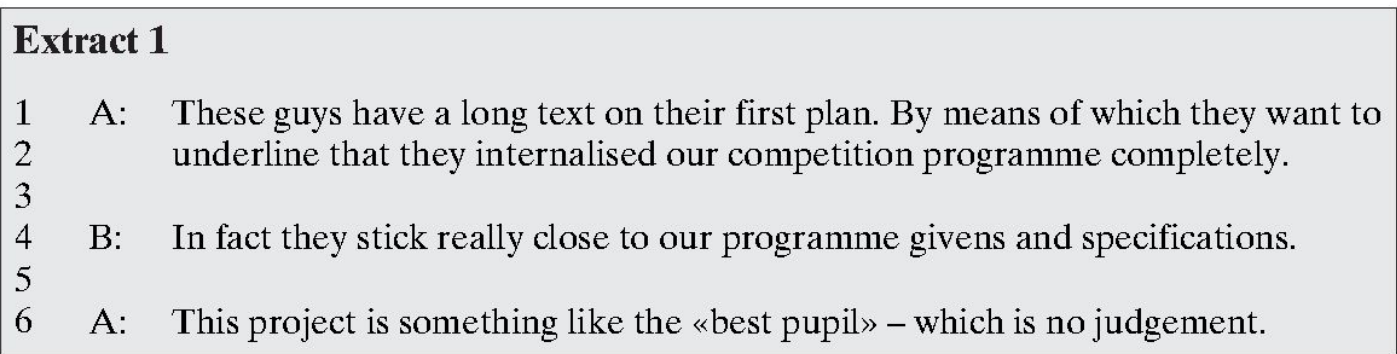

not enough to simply work through the list of givens and specifications but to integrate them into a consistent project which convinces or even surprises the jury on an overall level. But how can a competition programme provoke these skills and at the same time make sure that the binding requirements are clearly communicated? How can the significantly limited space of possibilities (or solution space) as generated through a development study get re-widened without losing the knowledge or precision gained through the same study with regard to binding requirements?

KreINER (2009) states that the competing architecture offices

«make (and have to make) explicit and implicit judgments about the text of the brief - judgments that reflect a reading of the brief as instructions (delimiting the solution space), as indications (e.g. symbolizing the identity and values of the client organization) or as illustrations (providing inspiration for exploring what the client could get)» (2009: 10).

From this, one might jump to the conclusion that the translation, that is, the effort to transform a detailed request into a competition programme is not needed as the re-widening of the competition's space of possibilities comes almost naturally with the competing architecture offices' fancy and imagination. However, the observation results published here indicate that the way the givens and specifications of the programme are worded and presented in the competition brief clearly influences the competition's space of possibilities - an aspect the authors of the brief appear to be well aware of.

In the following extract, two laymen ( $\mathrm{A}$ and $\mathrm{B}$ ) and a professional architect $(\mathrm{C})$ discuss a draft version of the competition programme for the Basel Kunstmuseum extension competition. A, B and C are not only involved in writing the competition brief, they will also act as jurors later in the competition process (as is often the case). The following dialogue occurred as the authors were going through the list of spatial specifications.

The result of the discussion in extract 2 (p. 8) was an agreement to keep the exact square metre figures, but to attach the information that the foyer could «possibly be combinable with the connection wing» and the connection wing could «possibly be an extension to the foyer». Regarding the museum's shop it was formulated «that the foyer includes 20 square metres for information desk, shop and special exhibition» but the issue of allocation was purposely left up to the competing architecture offices (cf. the competition programme for the Basel Kunstmuseum, Burghof Extension, p. 22).

Juror A's remark (line 22) in extract 2 again indicates that the client/jury in an architectural competition does not seek a project that merely has processed all the givens and specifications. Aside from this, juror A's statements (line 1 , line 17/18 and line 23/24) indicate that by the time the competition brief is written, a quite clear and specific idea (an assemblage of wishes and restrictions) with regard to the future building's specifications has formed. A's statement in line 10/11 regarding the exact square metre specifications particularly indicates that this assemblage possesses rather sharp boundaries. In order to «generate scope» (line 24) for the competing architecture offices, this assemblage has to be «deterritorialised», that is, its boundaries have to be blurred to a certain extent (DELANDA 2006: 13). The decision to insist on the exact square metre figures but at the same time to leave the allocation of the rooms up to the competing architecture offices particularly demonstrates that this process of deterritorialisation is already organized by the authors of the brief and will not simply be performed by the competing architecture offices through their interpretation or (slight) «misreading» of certain programme givens and specifications.

The next example shows the conflicting relationship between provoking creativity on the one hand and guaranteeing the fulfilment of binding requirements on the other. It is drawn from the field notes of the author from a housing competition in Zurich. Since the site this competition targeted was particularly narrow and very steep, special emphasis was placed in the development study on a suitable concept for vehi- 


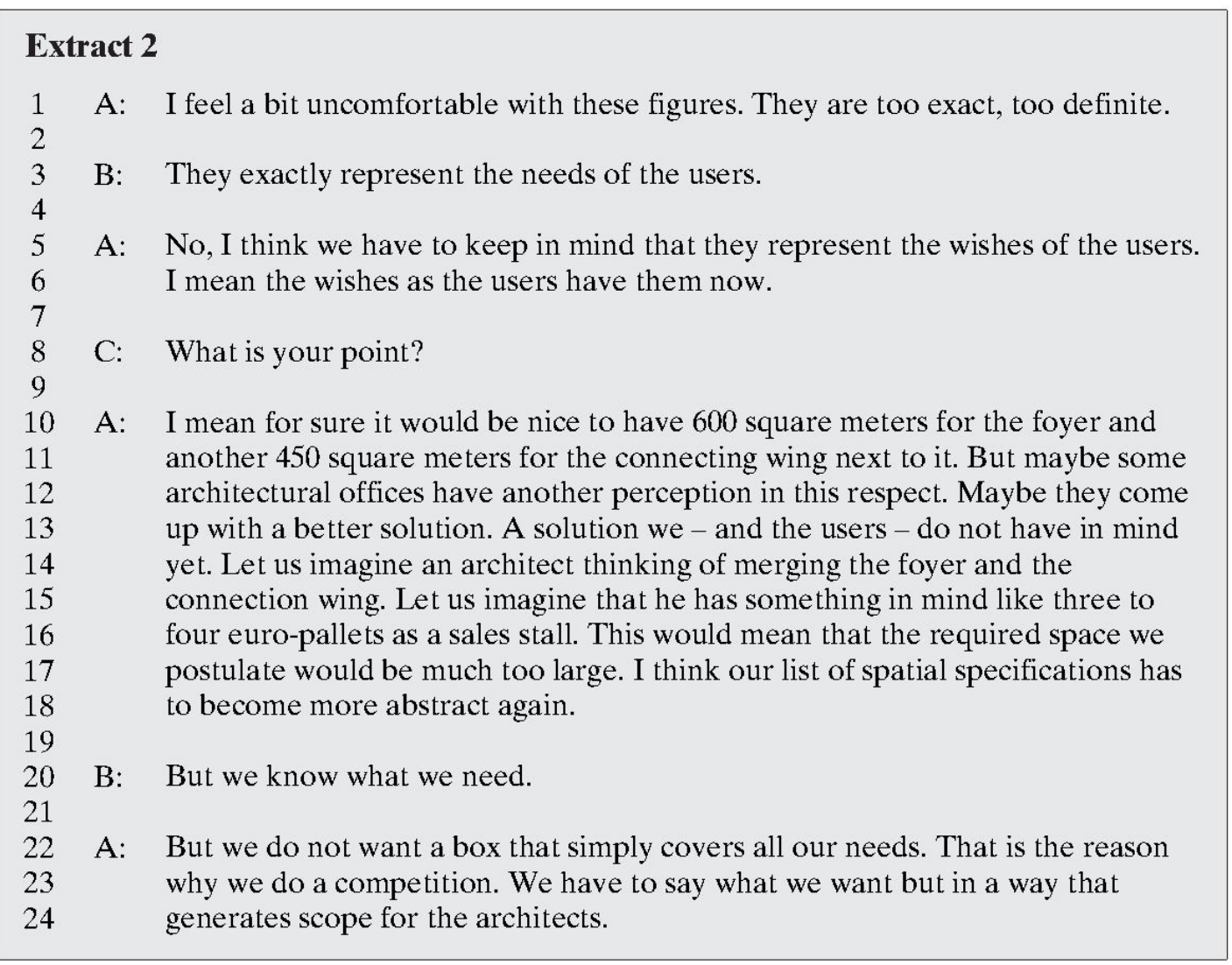

cle access. The development study recommended that the site be accessed from the north and that the existing road be broadened. Similar to extract 2, extract 3 presents a dialogue between three people talking about a draft version of the competition brief. All of the speakers are part of the team writing the brief Further, they are professional architects and will act as jurors of the competition later on. This discussion led to a final version of the brief which implemented B's suggestions in line 29 and 30.

Extract 3 (p. 9) demonstrates how the authors of the brief try to formulate a programme specification as clearly and as detailed as possible in order to provide hints as to how it should be understood. Extract 3 shows, in particular, that the intention of the authors is to prevent the competing architecture offices from speculating whether the point «access from the north» should be understood as an «instruction», «indication» or «illustration», to borrow KREINER's (2009) terms. The three brief authors and future jurors, A, B and $\mathrm{C}$, try to make clear that blurring the boundary of the assemblage of wishes and restrictions with regard to the point «accessing the site» is not recommended. The way that this point is formulated and represented in the final version of the brief, i.e., with reference to the attached detailed development study made by a well- regarded architecture office which specifically recommends accessing the site from the north, clearly indicates that a better way of accessing the site is difficult (or even impossible) to find. This formulation, thus, makes this programme specification in fact (almost) an instruction.

During the observation period, it became clear that the authors of the brief worked through the whole programme repeatedly to identify critical points (similar to those cited in extracts 2 and 3 ). They then made particular effort to provide as much and as precise information as possible about these points, i.e., where a more «creative», more «open» interpretation of the programme specification is worth pursuing and where it is advisable or necessary to understand the specification as a «direct» instruction. It can therefore be noted that not only the competing architecture offices play with (or speculate about) the programme specifications (and in this way create a certain variety of solutions), but also the authors of the brief «play with the competing architecture offices» as well: they create formulations and speculate about how these formulations might interact with the competing architects, that is, what solutions (and what variety of solutions) they might create or provoke respectively. 


\begin{tabular}{|c|c|c|}
\hline \multicolumn{3}{|c|}{ Extract 3} \\
\hline $\begin{array}{l}1 \\
2\end{array}$ & A: & «Access from the north will be sought». That's too weak. \\
\hline 3 & B: & That's a good remark. You're absolutely right. We have to paraphrase that \\
\hline 4 & & point. In the programme we have to show what is technically possible in order \\
\hline 5 & & to give the architects a clear idea of the scope. We are looking for creativity. \\
\hline 6 & & Everywhere. Also when it comes to the underground parking. However the \\
\hline 7 & & site's main access point is rather finalized. We should indicate that we are open \\
\hline 8 & & to propositions we have not thought of. The architects are free to develop a \\
\hline 9 & & better solution than ours. But we should also indicate that the main focus of the \\
\hline 10 & & competition lies somewhere else and that we would recommend accessing the \\
\hline 11 & & site from the north since that solution is appreciated from nearly all sides, also \\
\hline 12 & & from the local residents. \\
\hline 13 & & \\
\hline 14 & A: & But how do we formulate that in the brief? \\
\hline 15 & & \\
\hline 16 & B: & I would suggest attaching the development study to the brief. In that way the \\
\hline 17 & & competing architects realize that we spent money and energy on that issue and \\
\hline 18 & & that we have reached a level they can build on. \\
\hline 19 & & \\
\hline 20 & $\mathrm{C}:$ & I would really favour that. In our last competition we were offering a large scope \\
\hline 21 & & considering the site's main access point. I think we used a similar formulation \\
\hline 22 & & but did not attach the development study we commissioned. If we look at that \\
\hline 23 & & competition in retrospect, I mean if we compare what we had on our desk \\
\hline 24 & & before that competition to what the competing architects submitted, we clearly \\
\hline 25 & & have to admit that providing that large a scope was not the right decision. We \\
\hline 26 & & should really assist the architects with the development study. So that they \\
\hline 27 & & don't have to - or do not - start from zero. \\
\hline 28 & & \\
\hline 29 & B: & So let's attach the study and make the respective line something like: «The \\
\hline 30 & & a \\
\hline
\end{tabular}

Chupin (2010) and Van Wezemael (2010: 281-282) both argue that architectural competitions imply three different judgements:

«The judgements which submitting planners (or architecture offices) make with regard to what they believe the jury might honour [author's comment: as well as to what they think is appropriate for the site concerned]; the judgement of the jury which eventually picks a winner and which unfolds in a relational space as opened up by the projects; and the judgement of the public with regard to the outcome of the competition, which is also, of course, a judgement on both of the prior ones».

Extracts 2 and 3, however, suggest viewing the judgement process in architectural competitions as fourfold since both extracts point out that the process of translating the definite idea or assemblage as generated through the development study into a competition programme involves judgement as well: the judgement of the authors of the brief with regard to how the competing architecture offices might interpret their formulations.
Thus, from the discussion above, it is clear how the list of programme specifications, and especially the way they are formulated and presented, generates a space of possibilities. However, when discussing competition briefs one must not forget the fact that they do not just comprise the list of specifications but also feature a list of jury members as well as a list of evaluation and assessment criteria.

It is argued here that the latter list has no influence on the definition of the competition's solution space as almost every competition programme draws on exactly the same list of key criteria. Although these criteria may be worded differently and grouped in different ways (as the borders between the criteria are diffuse), a set of roughly five key criteria apply in every architectural competition: urban design, architecture, functionality, cost effectiveness and ecological sustainability. In the brief for the Basel Kunstmuseum extension, for instance, the set of key criteria (Chapter 4, «Evaluation and Assessment Criteria»,p. 33) is formulated as follows: 
- Urban design and planning, integration into the building history and context

- Architecture

- Functionality of the building operation, meeting the special specifications

- Operating feasibility; compliance with the budget; cost-efficient maintenance and operation

- Ecological sustainability.

In contrast to this highly generalized list, the list of jury members can definitely influence the competition's solution space. As JACK L. NASAR (1999: 152-153) writes:

«In selecting the professional advisor and jury, the client is probably selecting the winner. According to the architect STEVEN IzenOuR, <clients who use design competitions don't understand that by picking the jury you're in fact picking the architect. (...) > Similarly, the British Secretary of the Royal Fine Arts Commission asserted: ‘The crucial decision is to appoint the jury. If you want a Classical building set up a jury that is likely to award it to a Classicist. »»

Or, as CHupin (2010) argues: one cannot ignore judges' preconceptions - the same way one cannot imagine that a designer approaches his project without preconceptions. CHUPIN further points out that numerous well-known researches have shown preconceptions do not only filter the view of the designer, but that they have a determining, in fact, a necessary role, in the launch of the design process. Referring to ScHöN (1983) and DARKE (1979), who spoke of these preconceptions as a «primary generator» (a broad initial objective or small set of objectives, self-imposed by the architect, a value judgement rather than the product of rationality), CHUPIN (2010) asks: How can one deny the fact that each member of a jury carries their own preconceived ideas, if not their prejudices? According to KREINER (2007b), competing architecture offices construct an image of the client/jury by speculating about the client's/jury's preferences and tastes in order to gain a better understanding of what is being looked for in the competition. Against this background two aspects become clearer:

a) when wondering if they should enter a certain competition, architecture offices take the list of jurors into account, that is, they speculate about the jurors' preconceived ideas with regard to the task at hand;

b) when taking part in the competition, architecture offices might bring their projects into line with what they think the jury members will like.

Although this paper does not offer empirical data to support the following statement (since it was not the focus of the field research presented), it appears very likely that the publication of the jury panel - be it intended or not - constitutes a sorting process in the sense that it creates an adjusted field of applying architects (mainly architects who consider their preconceptions - and as a consequence their architectural propositions - to be more or less in line with those of the jury board) and in that way obviously manipulates the competition's space of possibilities.

\section{Conclusion}

This paper offers observational data to support the hypothesis that the writing of a competition programme is an important part of the process of organizing an architecture competition's space of possibilities. It argues that the process of translating a detailed request (which reflects a client's initial request and includes an elaborated development study) into a competition programme should be considered a fourth process of judgement in the set of judgement processes formulated by VAN WEZEMAEL (2010) and CHUPIN (2010). Further, it complements KREINER's (2009) observation of the judgement process involved in the interpretation of the competition brief by the competing offices with the judgement process involved in the formulation of the brief by the authors themselves (with regard to how they assume the competing architecture offices might interpret their formulations). Extract 2 shows how the authors of the brief tried to generate scope for the competing architecture offices, that is, to re-widen the competition's space of possibilities. Extract 3 shows how they tried to determine the outcome of the competition with regard to certain features, that is, to narrow the competition's space of possibilities.

The complex nature of the interplay of the four processes of judgement in the course of an architectural competition makes it impossible to exactly predict the solutions the competition will generate. Still, if one thinks of an axis defining the role an architectural competition may play - an axis ranging from an extremely narrow space of possibilities at one end (a competition considering a project which is almost entirely determined) to an extremely wide space at the other end (a competition which searches for far-reaching and possibly unforeseen architectural propositions) - it can be postulated that the competition brief (including the list of jurors) is a tool to carefully position the architectural competition on this axis. As such, it is an instrument to adjust the competition's solution space or its space of possibilities to the problem at hand, thereby making it useful for setting up an effective competition. «A competition's success depends fifty percent on a sound and precise competition programme» as Fritz Schumacher, Kantonsbaumeister Basel-Stadt (Cantonal Master Planner for Basel-City), put it in a personal communication to the author on the 27 th of April 2009. 


\section{References}

The Competition Programme for «The Basel Kunstmuseum, Burghof Extension» - An anonymous project competition in a selective procedure, published on April 27th 2009.

Chupin, J.-P. (2010): Analogie et théorie en architecture (De la vie, de la ville et de la conception, même). - Gollion: Infolio.

DARKE, J. (1979): The primary generator and the design process. - In: Design Studies 1, 1:36-44.

DELANDA, M. (2002): Intensive science and virtual philosophy. - London, New York: Continuum.

DeLanda, M. (2006): A new philosophy of society. Assemblage Theory and social complexity. - London, New York: Continuum.

GeERTz, C. (1975): The interpretation of cultures. London: Hutchinson.

KoHouteK, R. (2005): Der unmögliche Wettbewerb. In: Ö. G. f. Architektur (ed.): Wettbewerb! Competition! - In: UmBau 22, Wien: 124-129.

KreINER, K. (2006): Architectural competitions - a case study. - http://www.clibyg.org/en/knowledge_ bank/index.php?item_id=21 03.05.2010.

KREINER, K. (2007a): Strategic choices in unknowable worlds. - http://www.clibyg.org/en/knowledge_bank/ index.php?item_id=33 03.05.2010.

KreINER, K. (2007b): Constructing the client in architectural competition. - http://www.clibyg.org/en/ knowledge_bank/index.php?item_id=11 03.05.2010.

KreINER, K. (2009): Architectural competitions. Empirical observations and strategic implications for architectural firms. - http://www.clibyg.org/en/knowledge_bank/index.php?item_id=56 03.05.2010.

Latour, B. \& S. Woolgar (1979): Laboratory life. The social construction of scientific facts. - Princeton: Princeton University Press.

NASAR, J.L. (1999): Design by competition. Making design competition work. - Cambridge: Cambridge University Press.

PLøGER, J. (2008): Foucault's dispositif and the city. In: Planning Theory 7, 1: 51-71.

SснӧN, D.A. (1983): The reflective practitioner: How professionals think in action. - London: Temple Smith. Schumacher, F. (2009): Cantonal Master Planner for Basel-City, personal communication, 27th of April 2009. Sorkin, M. (2005): Democracy degree zero. - In: Ö. G. f. Architektur (ed.): Wettbewerb! Competition! - In: UmBau 22, Wien: 105-116.

VAN WeZEMAEL, J.E. (2010): Modulation of singularities - a complexity approach to planning competitions. - In: Hillier, J. \& P. Healey (eds): Conceptual challenges for Planning Theory. - Aldershot: Ashgate: 273-289.

Van Wezemael, J.E., Silberberger, J.M., Paisiou, S. \& P. FreY (2011): «Mattering» the Res Publica - Swiss architectural competitions as a foucauldian dispositif. - In: disP 1/2011: 52-59.
WeICK, K.E. (2006): The role of imagination in the organizing of knowledge. - In: European Journal of Information Systems 15: 446-452.

Yaneva, A. (2009): The making of a building: a pragmatist approach to architecture. - Bern: Peter Lang.

\section{Summary: Organizing the space of possibilities of an architectural competition}

In order to develop an idea before conducting an architectural competition, clients often select an architectural office to carry out a «development study». Within the scope of such a study different possible volumetric variants are produced exploring how the client's request might look in consideration of given restrictions (budget, planning and building laws and regulations). Thereby, and in particular by means of the accompanying regular exchange between the employees of the architectural office and the client's representatives, the client's idea becomes more and more clear, definite and detailed. Drawing on findings of an ethnographic study of four on-going architectural competitions in Switzerland, this article describes how the authors of the competition programme translate such a detailed request (or definite idea) into a document that both generates scope for the competing architectural offices, as well as constrains them by expecting the fulfilment of specific requirements. Put differently, the paper investigates how the authors of a competition programme organize the competition's space of possibilities.

Keywords: architectural competition, competition programme, space of possibilities, ethnography, Switzerland

\section{Zusammenfassung: Zur Organisation von Möglich- keitsräumen bei einem Architekturwettbewerb} Um vor der Durchführung eines Architekturwettbewerbs das betreffende Bauvorhaben zu präzisieren, geben viele Bauherren eine «Potentialstudie» in Auftrag. Im Rahmen einer solchen Studie werden verschiedene mögliche volumetrische Varianten entwikkelt, die aufzeigen, wie das Bauvorhaben angesichts der gegebenen Restriktionen (Budget, Baurecht und städtebauliche Vorgaben) aussehen kann. Dadurch und im Besonderen durch den begleitenden regelmässigen Austausch zwischen Angestellten des beauftragten Architekturbüros und Repräsentanten der Bauherrschaft wird das Bauvorhaben immer klarer, präziser und detaillierter. Die vorliegende Arbeit stützt sich auf Ergebnisse einer ethnographischen Studie von vier laufenden Architekturwettbewerben in der Schweiz. Sie zeigt auf, wie die Autoren des Wettbewerbsprogramms den Möglichkeitsraum des Wettbewerbs organisieren, indem sie ein detailliertes Bauvorhaben in ein Dokument übersetzen, das den 
Wettbewerbsteilnehmern Spielraum eröffnet, gleichzeitig aber garantiert, dass angemessene architektonische Vorschläge produziert werden.

Schlüsselwörter: Architekturwettbewerb, Wettbewerbsprogramm, Möglichkeitsraum, Ethnographie, Schweiz

\section{Résumé: Organiser l'espace des possibilités d'un concours architectural}

Avant de lancer un concours d'architecture, les clients sélectionnent souvent un bureau d'architecte pour procéder à une étude préliminaire permettant de préciser leurs demandes. Ce genre d'étude permet d'explorer différents volumes et de réfléchir à l'adéquation entre les désirs du client et les différentes contraintes qui s'exercent sur son projet (budget, lois relatives à la planification et aux constructions). De cette façon, grâce en particulier aux échanges réguliers entretenus entre les employés du bureau d'architecture et les représentants du client, les attentes du client deviennent plus claires, précises et détaillées. S'appuyant sur les résultats d'une étude ethnographique conduite sur quatre concours en Suisse, cet article décrit comment les auteurs des programmes des concours architecturaux traduisent les attentes (ou l'idée précise) des clients en un document qui laisse suffisamment de place aux bureaux d'architectes pour exprimer leurs idées et qui tienne également compte des contraintes spécifiques du projet. En d'autres termes, l'article examine comment les auteurs des programmes de concours organisent l'espace des possibilités architecturales.

Mots-clés: concours d'architecture, programme de concours, espace des possibilités, ethnographie, Suisse

Jan Silberberger, PhD Candidate, University of Fribourg, Department of Geosciences, Geography Unit, Chemin du Musée 4, CH-1700 Fribourg, Switzerland. e-mail: jan.silberberger@unifr.ch

Manuskripteingang/received/manuscrit reçu le 5.11.2010

Annahme zum Druck/accepted for publication/accepté pour publication: 17.3 .2011 